\title{
EKSISTENSI ROADSTEADS DAN PEMANFAATAN HAK EKONOMI DI LAUT
}

\author{
Marlina \\ Fakultas Hukum Universitas Surabaya \\ Jl. Raya Kali Rungkut, Rungkut, Surabaya, 60293 \\ Email: lina@staff.ubaya.ac.id
}

\begin{abstract}
Roadsteads are part of the territorial sea. The function of Roadsteads in the utilization of economic rights at sea lies in the purpose of keeping in the form of surveillance, prevention of violations and law enforcement in the territorial sea. By default the setting of the 12-mile freeway is an additional zone where special and limited jurisdiction is applicable. So the role for keeping purpose can still be applied in the zone. While on the purpose of managing the fields in ZEE and LK then the existence of Roadsteads as facilities provided by the State coast as one form of temporary arrangement. This form of provisional arrangement is directed at the sustainable use of economic rights. UNCLOS stipulates that temporary, practical arrangements can be taken in the event that there are slices in ZEE and LK between two opposing and contiguous States. Where the utilization of economic rights at sea that provides opportunities to other countries are in space ZEE and LK. The room where there are many violations due to the unfinished issue of mutually agreed limitations. The existence of Roadsteads is able to answer the pattern of maintaining and managing related to the utilization of economic rights at sea. Through library search and related rules, the author tries to provide conceptual answers in the study of Roadsteads and the utilization of economic rights at sea.
\end{abstract}

Keywords: Roadsteads, Temporary Regulation, Economic Rights

\begin{abstract}
Abstrak
Roadsteads merupakan bagian dari laut teritorial. Fungsi Roadsteads dalam pemanfaatan hak ekonomi di laut terletak pada tujuan menjaga dalam bentuk pengawasan, pencegahan pelanggaran dan penegakan hukum di laut teritorial. Secara baku penetapan batas lepas 12 mil adalah zona tambahan dimana berlaku yurisdiksi khusus dan terbatas. Sehingga peran untuk tujuan menjaga masih dapat diterapkan di zona tersebut. Sedangkan pada tujuan mengelola yang menjadi ladang di ZEE dan LK maka keberadaan Roadsteads sebagai fasilitas yang disediakan Negara pantai sebagai salah satu bentuk pengaturan sementara. Bentuk pengaturan sementara tersebut diarahkan pada pemanfaatan hak ekonomi yang berkelanjutan. UNCLOS mengatur bahwa pengaturan sementara yang bersifat praktis dapat ditempuh dalam hal terdapat irisan di ZEE dan LK antara dua Negara yang saling berhadapan dan berdampingan. Dimana pemanfaatan hak ekonomi di laut yang memberikan kesempatan kepada Negara lain berada di ruang ZEE dan LK. Ruang dimana justru banyak terjadi pelanggaran karena belum selesainya persoalan penetapan batas yang disepakati bersama. Keberadaan Roadsteads diharapkan dapat menjawab pola pernjagaan dan pengelolaan terkait pemanfaatan hak ekonomi di laut. Melalui penelusuran pustaka dan aturan terkait, penulis mencoba memberikan jawaban terkonsep dalam kajian Roadsteads dan pemanfaatan hak ekonomi di laut.
\end{abstract}

Kata Kunci: Roadsteads, Pengaturan Sementara, Hak Ekonomi 


\section{A. PENDAHULUAN}

Laut adalah ruang perairan di muka bumi yang menghubungkan daratan dengan daratan dan bentuk-bentuk alamiah lainnya, yang merupakan kesatuan geografis dan ekologis beserta segenap unsur terkait, dan yang batas dan sistemnya ditentukan oleh peraturan perundangundangan dan hukum internasional. Definisi ini diatur dalam Undang-Undang Nomor 32 Tahun 2014 tentang Kelautan.

Sebagai ruang perairan yang berbeda sifat dengan ruang di darat, pengaturan untuk menjaga dan mengelola sumber daya alamnya juga berbeda. Dimana pengelolaan sumber daya kelautan dilakukan melalui sebuah kerangka hukum untuk memberikan kepastian hukum dan manfaat bagi seluruh masyarakat sebagai Negara kepulauan yang berciri nusantara. Artinya kebijakan untuk menjaga dan mengelola sumber daya alam laut yang selanjutnya akan ditulis sda laut harus memberikan kepastian hukum dan nilai manfaat.

Pengaturan yang memberikan kepastian hukum dan nilai manfaat di ruang laut terbagi dalam zona-zona menurut hukum internasional. Sebagaimana diketahui, bahwa usaha masyarakat internasional untuk mengatur masalah kelautan telah ditandatangani di Montego Bay, Jamaica pada tanggal 10 Desember 1982 dengan memberlakukan UNCLOS (The United Nations Convention on the Law of the Sea).

Ditinjau dari isinya, UNCLOS 1982 merupakan:

1. Sebagian merupakan kodifikasi ketentuan-ketentuan hukum laut yang sudah ada, misalnya kebebasan-kebebasan di Laut Lepas dan hak lintas damai di Laut Teritorial

2. Sebagian merupakan pengembangan hukum laut yang sudah ada, misalnya ketentuan mengenai lebar Laut Teritorial menjadi maksimum 12 mil laut dan kriteria Landas Kontinen.

3. Sebagian melahirkan rejim-rejim hukum baru, seperti asas Negara kepulauan, Zona Ekonomi Eksklusif dan Penambangan di Dasar Laut Internasional.

Bagi bangsa Indonesia, arti penting UNCLOS menjadi penguatan dan pengakuan sebagai Negara kepulauan. Dimana sebelumnya asas Negara kepulauan belum diakui dan diatur dalam hukum internasional. Hal ini masih menyisakan beberapa problem kelautan misalnya perairan yang dulunya merupakan bagian dari Laut Lepas berubah status dan kegunaan menjadi bagian ruang perairan Negara kepulauan tersebut.

Selanjutnya dalam UNCLOS diatur pula zona-zona terkait yurisdiksi, kewenangan dan hak kewajibannya. Zona-zona tersebut antara lain:

1. Zona berada di bawah kedaulatan penuh suatu Negara: laut teritorial, laut pedalaman dan selat untuk pelayaran internasional dengan hak lintas transitnya.

2. Zona berlaku yurisdiksi khusus dan terbatas di zona tambahan

3. Zona hak berdaulat untuk memanfaatkan hak ekonomi di zona ekonomi eksklusif (ZEE) dan landas kontinen (LK) 
4. Zona yang berada di bawah pengaturan badan internasional di kawasan dasar laut internasional

5. Zona yang tidak berada di bawah kekuasaan maupun kedaulatan negara manapun di laut lepas.

Penetapan zona-zona di atas membawa implikasi pengaturan hukum dan kewenangan yang berbeda sekaligus hak-kewajiban Negara pantai maupun Negara lain sebagai pengguna dan pemanfaat. Sebagai Negara kepulauan, Indonesia memiliki kepentingan untuk mengatur zona 1-3. Sedangkan, zona 4 dan 5 tidak ada kewenangan negara manapun untuk mengatur dan menguasainya. Di laut teritorial, Negara pantai memiliki batas kedaulatan penuh yang diikuti dengan hak lintas damai. Sehingga Negara pantai berhak membuat peraturan tentang lintas laut damai yang termasuk di dalamnya pengaturan lintas laut.

Di Zona tambahan, Negara pantai dapat melaksanakan pengawasan dan pengendalian yang perlu, untuk:

1. Mencegah pelanggaran terhadap peraturan perundang-undangannya di bidang bea cukai, fiskal, keimigrasian dan kesehatan yang berlaku di wilayah darat dan laut teritorial Negara pantai;

2. Menindak pelanggaran-pelanggaran atas peraturan perundang-undangan tersebut yang dilakukan di wilayah darat dan laut territorial Negara pantai.

Di zona hak berdaulat, yaitu ZEE dan LK maka Negara pantai memiliki kewenangan yang besar untuk tujuan pengelolaan hak ekonomi di laut. Arti kata pengelolaan tidak hanya terletak pada tujuan eksplorasi dan eksploitasi, namun juga ada kewajiban untuk memberikan kesempatan terutama kepada Negara tidak berpantai atau Negara yang secara geografis tidak beruntung untuk turut serta memanfaatkan surplus dari jumlah tangkapan ikan yang diperbolehkan. Penerapan sharing profit ini utamanya adalah untuk melakukan kompromi kepentingan antara Negara pantai, Negara yang tidak berpantai dan Negara yang pantainya saling berhadapan dan berdampingan. Sehingga pengakuan atas kebebasan pelayaran/ penerbangan melalui ZEE menimbulkan konsekuensi bahwa hak pemanfaatan ekonomi bersama terletak di kolom / tubuh air bukan pada permukaan ataupun pada dasar lautnya.

Karakteristik ini yang membedakan antara ZEE dan LK, dimana yang menjadi pusat pengaturan untuk pemanfaatan hak ekonomi di LK terkonsentrasi pada dasar atau yang melekat pada dasar lautnya. Hal mana baik di ZEE maupun di LK, pemanfaatan hak ekonomi lebih banyak pada bentuk pengambilan hak ekonomi, pemanfaatan dan fungsi pembagian porsi kemampuan eksploitasi. Menjadi persoalan, apabila antara dua Negara pantai yang memiliki irisan baik di ZEE dan LK belum melakukan kesepakatan untuk menyelesaikan batas yang menimbulkan tumpang tindih dan klaim sepihak. UNCLOS tidak membenarkan tindakan klaim sepihak dari Negara untuk penyelesaian batas wilayah tumpang tindih di laut, namun untuk penyelesaian di ruang ZEE dan LK, diatur apa yang dinamakan pengaturan sementara bersifat praktis ketika terjadi irisan kepentingan dan pemanfaatan hak ekonomi untuk tujuan pemanfaatan hak ekonomi bersama. 
Salah satunya adalah adanya hak transit ke dan dari laut melalui wilayah Negara pantai/ Negara transit. Sehingga melalui pemikiran yang penulis konsepkan, muncul sebuah pertanyaan yang coba dijawab dalam penelitian ini, yaitu apakah keberadaan roadsteads dapat menjawab pola penjagaan dan pengelolaan terkait pemanfaatan hak ekonomi di laut

\section{B. PEMBAHASAN}

International Hydrographic Organization $(\mathrm{IHO})^{1}$ mendefinisikan bahwa Roadstead adalah sebagai daerah dekat pantai dimana kapal dimaksudkan untuk berhenti dalam posisi aman dan sering singgah di lekukan dangkal pantai. Dalam studi yang dilakukan oleh badan PBB dalam bentuk "UN Office for Ocean Affairs and the Law of the Sea" pada kasus kebanyakan ditemukan, Roadstead tidak terlalu dijelaskan batas geografis alamnya. Posisi Roadstead ini pada umumnya diindikasikan dengan nama geografisnya saja pada peta. Apabila Pasal 12 UNCLOS diberlakukan, maka batas-batas yang disebutkan dalam pasal tersebut harus dijelaskan dalam pola atau dideskripsikan dengan daftar koordinat geografis.

Pasal 12 UNCLOS menyatakan bahwa roadstead adalah tempat berlabuh di tengah laut yang biasanya dipakai untuk memuat, membongkar dan menambat kapal, dan yang terletak seluruhnya atau sebagian di luar batas luar laut territorial, termasuk dalam laut territorial. Ditegaskan pula, bahwa kapal-kapal yang melalui Roadstead harus memenuhi prinsip sebagaimana dijelaskan dalam Pasal 18 (2) UNCLOS bahwa lintas harus terus-menerus, langsung serta secepat mungkin. Namun yang menjadi penekanan adalah Roadstead hanya dapat digunakan sebagai tempat berlabuh dalam keadaan-keadaan tertentu (force majeure) atau dalam tujuan memberikan bantuan. Dengan demikian Roadstead merupakan fasilitas untuk dimanfaatkan dalam rangka penggunaan hak lintas damai.

Pengertian lintas damai adalah aktivitas lintas yang tidak menimbulkan akibat membahayakan kedamaian, ketertiban atau keamanan Negara pantai. Sehingga semua yang merugikan bagi kedamaian, ketertiban atau keamanan Negara pantai bukanlah lintas kapal asing yang damai. UNCLOS mengatur bahwa yang harus dianggap membahayakan kedamaian, ketertiban atau keamanan Negara pantai meliputi:

1. Melakukan ancaman atau penggunaan kekerasan, mengumpulkan informasi atau propaganda yang merugikan terhadap kedaulatan, keutuhan wilayah atau kemerdekaan politik, dan pertahanan atau keamanan Negara pantai;

2. Melakukan latihan senjata, peluncuran, pendaratan atau penerimaan setiap peralatan dan perlengkapan militer, maupun pesawat udara dari atas kapal;

3. Melakukan bongkar atau muat komoditi, mata uang atau orang yang bertentangan dengan peraturan perundang-undangan Negara pantai;

4. Melakukan kegiatan perikanan, pencemaran, riset atau survey, mengganggu sistem komunikasi atau setiap fasilitas atau instalasi lainnya Negara pantai, maupun kegiatan lainnya yang tidak berhubungan langsung dengan lintas.

${ }^{1}$ Robin R Churchill, Oxford Public International Law: Roadsteads (http://opil.ouplaw.com, 15 March 2016 
Pasal 18 (1) UNCLOS mengatur bahwa lintas berarti navigasi melalui laut teritorial untuk keperluan:

1. Melintasi laut tanpa memasuki perairan pedalaman atau singgah di tempat berlabuh di tengah laut (roadstead) atau fasilitas pelabuhan di luar perairan pedalaman; atau

2. Berlalu ke atau dari perairan pedalaman atau singgah di tempat berlabuh di tengah laut (roadstead) atau fasilitas pelabuhan tersebut.

Artinya penegasan dalam pasal ini, bahwa Negara pantai memiliki fungsi pengawasan, pencegahan pelanggaran sekaligus penegakan hukum terhadap kapal-kapal yang melintas melalui laut teritorial. Keberadaan Roadstead sebagai dermaga tengah laut atau dermaga apung menjadi pola jawaban untuk menjaga sumber daya alam yang ada di laut.

Letak dari pelabuhan di tengah laut ini adalah seluruhnya atau sebagian di luar batas laut teritorial dan termasuk dalam laut teritorial menurut UNCLOS. Konsekuensi yang harus dihadapi apabila menyebut batas seperti di atas adalah perairan diantara Roadstead dan apa yang kira-kira dijadikan sebagai batas terluar dari laut teritorial juga termasuk wilayah laut territorial. UNCLOS tidak menyebutkan dengan jelas, namun persoalan batas untuk laut territorial secara tegas diatur dalam Pasal 15 manakala terjadi tumpang tindih untuk Negara pantai yang berhadapan dan berdampingan. Solusi yang ditawarkan adalah salah satunya dengan menarik garis tengah (median line). Ketentuan ini dapat disimpangi, apabila terdapat alasan hak historis atau keadaan khusus lain. Maka Negara dengan pantai berhadapan dan berdampingan di irisan laut teritorial dapat menggunakan cara dengan membuat persetujuan yang lain. Manakala tidak terjadi irisan di laut teritorial, maka keberadaan Roadstead masih berada di dalam zona dimana berlaku yurisdiksi khusus dan terbatas, yaitu pada zona tambahan.

Di zona tambahan, keberadaan Roadstead masih difungsikan sebagai peran untuk menjaga sumber daya alam di laut. Pola menjaga ini terbentuk dari karakteristik zona tambahan yang pada prinsipnya merupakan jalur laut 12 mil laut setelah batas laut teritorial. Artinya lapisan yang ditemui setelah laut teritorial adalah wilayah zona tambahan. Hak yang diberikan bagi Negara pantai adalah untuk penerapan hukumnya dan sekaligus guna mencegah terjadinya pelanggaran. ${ }^{2}$

Keberadaan Roadsteads sebagai tempat berlabuh yang esensinya adalah tempat persinggahan sementara dalam keadaan force majeure dapat menjadi pintu pengawasan terkait pemberian hak pengejaran seketika terhadap kapal asing yang diduga telah melanggar peraturan perundang-undangan Negara pantai. Pasal 111 UNCLOS mengatur bahwa pengejaran seketika dapat dilakukan dengan pengejaran yang tidak terputus, yang boleh diteruskan hingga di luar laut territorial atau zona tambahan, sejak diketahuinya kapal asing atau sekocinya ada dalam perairan pedalaman, perairan kepulauan, laut teritorial atau zona tambahan Negara pengejar. Hak pengejaran seketika ini juga berlaku secara mutatis mutandis bagi pelanggaran-pelanggaran di ZEE atau di LK. Sehingga dengan keberadaan Roadsteads,

${ }^{2}$ Tjondro Tirtamulia, zona-zona laut UNCLOS hal. 24,Brilian Internasional Surabaya 2011 
kapal asing yang diduga telah melakukan pelanggaran dapat ditindak dengan tegas sesuai peraturan perundang-undangan Negara pantai.

Keberadaan Roadsteads di ZEE dan LK, menjadi konsep pengaturan sementara yang bersifat praktis. Adanya hak lintas damai di laut teritorial, sedangkan hak lintas transit berlaku bagi selat yang digunakan untuk pelayaran internasional antara satu bagian laut lepas atau ZEE dan bagian laut lepas atau suatu ZEE lainnya. Pasal 37-44 UNCLOS mengatur dengan tegas mengenai konsep hak ini.

Lintas transit tidak berlaku apabila pada sisi kearah laut pulau tujuan terdapat suatu rute melalui laut lepas atau melalui ZEE yang sama fungsinya dengan tujuan navigasi dan hidrografis. Lintas transit dilakukan terus-menerus, langsung dan secepat mungkin antara satu bagian laut lepas atau ZEE dan bagian laut lepas atau ZEE lainnya. Namun demikian, tidak menutup kemungkinan bagi lintas melalui selat untuk maksud memasuki, meninggalkan atau kembali dari suatu Negara yang berbatasan dengan selat itu, dengan tunduk pada syarat-syarat masuk Negara itu. Artinya di zona dimana terdapat hak pembagian hak ekonomi, dimungkinkan pula digunakannya hak lintas transit.

Sebagai Negara kepulauan, Indonesia juga memiliki kewajiban menetapkan suatu alur untuk dilintasi dalam laut kepulauan. Artinya pelaksanaan hak pelayaran dan penerbangan sesuai dengan ketentuan-ketentuan Konvensi untuk melakukan transit yang terus-menerus, langsung dan secepat mungkin serta tidak terhalang antara satu bagian laut lepas atau ZEE dan bagian laut lepas atau ZEE lainnya.

Sebagaimana dipaparkan sebelumnya, bahwa di ZEE dan LK, berlaku apa yang dinamakan hak berdaulat, artinya tidak tunduk pada kedaulatan penuh Negara pantai. Namun Negara pantai hanya dapat melakukan pengelolaan perairan yang juga memberikan hak kebebasan bagi Negara lainnya. Dengan demikian, sebenarnya zoan ini menyerupai laut lepas yang dilekati hak berdaulat Negara pantai. Sehingga dalam zona ini berlakulah prinsip sui generis bagi Negara pantai, yang tidak berlaku di laut lepas yang sebenarnya dimana tidak dapat dimiliki oleh suatu Negara manapun.

Penentuan lebar ZEE yang tidak melebihi 200 mil laut pada awalnya merupakan persoalan yang erat kaitannya dengan masalah penetapan lebar laut teritorial yang tidak melebihi atau maksimal 12 mil laut. Hal ini dikarenakan:

1. Pada beberapa Negara paantai, yang menganut lebar laut teritorial 200 mil laut, baru dapaat menerima penetapan lebar laut teritorial maksimal 12 mil laut dengan adanya rezim ZEE yang lebarnya tidak melebihi 200 mil laut.

2. Namun pada sisi lain:

a. Bagi Negara tidak berpantai dan bagi Negara yang secara geografis tidak beruntung baru dapat menerima penetapan ini karena memperoleh kesempatan untuk turut serta memanfaatkan surplus dari jumlah tangkapan yang diperbolehkan;

b. Mempunyai hak transit ke dan dari laut melalui wilayah Negara pantai atau Negara transit. 
3. Negara-negara maritim dapat menerima keberadaan rezim khusus ini, jika Negara pantai tetap menghormati kebebasan pelayaran dan atau penerbangan melalui zona ini.

Artinya termuat sharing profit terkait pemanfaatan hak ekonomi di zona ini dalam kapasitas pembagian porsi kemampuan eksploitasi antara Negara pantai dan Negara lainnya. Permasalahannya adalah bagaimana kontruksi pembagiannya bilamana penetapan batas antara Negara pantai yang berhadapan dan berdampingan memiliki irisan kepentingan yang belum terselesaikan.

Pasal 74 dan 83 UNCLOS memberikan kesempatan kepada Negara pantai untuk melakukan pengaturan sementara selama menunggu masa peralihan sampai tercapainya kesepakatan antara Negara yang menjadi pihak. Keberadaan Roadsteads dapat menjadi salah satu bentuk pengaturan sementara, dalam artian fungsi yang diperankan bukan lagi sebagai pengawas, pencegahan pelanggaran dan sekaligus penindak. Karena sifat yang melekatinya adalah hak berdaulat, maka peran yang dijalankan adalah dalam fungsinya sebagai pengendali untuk pemanfaatan hak ekonomi yang ditujukan untuk berkelanjutan. Mekanismenya adalah Roadsteads menjadi dermaga apung yang ada di tengah laut yang berfungsi dalam mengakomodir hak transit ke dan dari laut melalui wilayah Negara pantai atau Negara transit.

Baik sebagai Negara pantai maupun Negara transit, keberadaan Roadsteads dapat menjadi konsep awal untuk memberikan ruang pengaturan bagi kepentingan selanjutnya. Artinya, menjadi titik awal bagi Negara untuk menyelesaikan penetapan batas wilayahnya di irisan ZEE maupun LK.

Letak Roadsteads yang adalah seluruhnya atau sebagian di luar batas laut teritorial dan menurut UNCLOS termasuk dalam laut teritorial memuat pengertian bahwa keberadaan Roadsteads ada di zona kedaulatan penuh suatu Negara pantai. Berlanjut di zona tambahan sebagai zona berlaku yurisdiksi khusus dan terbatas untuk fungsi pengawasan, pencegahan pelanggaran dan penegakan hukum. Sedangkan untuk zona hak berdaulat dimana hak ekonomi Negara pantai terlekati dengan hak Negara lain untuk menikmati surplusnya, maka keberadaan Roadsteads mengambil peran sebagai salah satu bentuk pengaturan sementara untuk penyelesaian batas di irisan yang belum terselesaikan. Termasuk di dalamnya untuk kebutuhan akomodir kepentingan hak lintas transit. Fungsinya akan berbeda di zona kedaulatan penuh suatu Negara pantai, karena perannya akan lebih banyak mengambil tujuan untuk diarahkan pada pemanfaatan hak ekonomi yang berkelanjutan. Harapannya dengan adanya Roadsteads, sebagai dermaga apung mampu menekan angka pelanggaran terhadap hak eksploitasi pemanfaatan sda di laut.

Satu kasus yang terjadi di sebuah Roadstead di Mogador (Morocco) ${ }^{3}$ yaitu "The Eastern City". Kasus ini menyangkut masalah keamanan di Roadstead, kapal Eastern City yang dicarter tersebut hendak berlabuh di Roadstead. Karena tidak ada standar keamanan dan Roadstead itu tidak memenuhi kemampuan untuk menanggung beban angin yang sangat kencang. Hal tersebut mengakibatkan kapal yang telah melepas jangkarnya untuk berlabuh

\footnotetext{
3 Alexander McKinnon, Administrative Shortcomings And Their Legal Implications In The Context Of Safe Ports,2009,23 A\&NZ Mar LJ
} 
gagal dan lepas. Kasus ini menyangkut ketidakamanan Roadstead, sehingga penting untuk diadakan aturan/ hukum terkait syarat administratif dari Roadstead. Hal mana ini juga merupakan tuntutan kerja cepat bagi Indonesia sebagai Negara kepulauan bilamana konsep Roadstead dapat diterima untuk menjaga dan mengelola sda di laut.

\section{PENUTUP}

Sebagai ruang perairan yang berbeda sifat dengan ruang di darat, pengaturan untuk menjaga dan mengelola sumber daya alamnya juga berbeda. Kebijakan untuk menjaga dan mengelola sumber daya alam laut dilakukan melalui sebuah kerangka hukum untuk memberikan kepastian hukum dan manfaat bagi seluruh masyarakat. Keberadaan Roadsteads dapat menjawab pola menjaga dan mengelola terkait pemanfaatan hak ekonomi di laut.

Fungsi menjaga dalam peran pengawasan, pencegahan pelanggaran dan penegakan hukum berlaku di zona kedaulatan penuh suatu Negara dan zona yursdiksi khusus dan terbatas yaitu di laut teritorial dan zona tambahan. Fungsi mengelola dalam peran akomodir hak lintas transit dan pemanfaatan hak ekonomi berkelanjutan berlaku di zona hak berdaulat yaitu ZEE dan LK. Dimana perbedaan keduanya terletak pada karakteristik hak ekonominya. ZEE di kolom atau tubuh laut, sedangkan LK untuk yang melekat pada dasar lautnya. Sebagai salah satu bentuk pengaturan sementara di irisan ZEE dan LK, Roadsteads dapat menjadi titik awal untuk Negara melakukan kerjasama dalam tujuan mencapai kesepakatan penyelesaian yang akan dipilih selanjutnya. Namun keberadaan Roadsteads juga memerlukan aturan/ hukum terkait syarat administratif sebagai standart keamanan. Hal mana merupakan tuntutan kerja cepat bagi Indonesia sebagai Negara kepulauan bilamana konsep Roadstead dapat diterima untuk menjaga dan mengelola sda di laut.

\section{DAFTAR PUSTAKA}

Churchill, Robin R. 2016. Roadsteads, Oxford Public International Law

Mc Kinnon,Alexander.2009. Administrative Shortcomings And Their Legal Implications In The Context Of Safe Ports: A\&NZ Mar LJ

Tirtamulia, Tjondro. 2011. Zona-Zona Laut UNCLOS: Brilian Internasional Surabaya

The United Nations Convention on the Law of the Sea (Konvensi Perserikatan BangsaBangsa tentang Hukum Laut), terjemahan Direktorat Perjanjian Internasional, Departemen Luar Negeri R.I.: Jakarta

Undang-Undang Nomor 32 Tahun 2014 tentang Kelautan. 